offentliches Recht und Volkerrecht. vol. 4. 1987. S. 67, 76-77; ezo sce: Die Verpfichtungen erga omnes im Volkerrecht und ihre Durchsetzung / Volkerrecht als Rechtsordnung Internationale Gerichtsbarkeit Menschenrechte. Festschrift fur H.Mosler. 1983. S. 255-257.

90. См.: Frowein J.A. Reactions by not Directly Affected States to Breaches of Public International Law // Recueil des Cours. 1994-IV. vol. 248. P. 400.

91. Резолюция 346 (1967) от 23 июня 1967 года. Yearbook. vol. 10. Р. 94-96.

92. Ibid. P. 586.

93. См.: Ibid. vol. 25. P. 7.

\title{
ЕВРОПЕЙСКИЙ ОМБУДСМАН
}

\author{
B. В. Бо й ц о в $\mathrm{a}^{*}$
}

Исторические традиции государств-членов ЕС благоприятствовали реализации на супранациональном уровне предложения о создании института Европейского Омбудсмана. Проблема взаимодействия национальных омбудсманов неоднократно становилась предметом заинтересованного обсуждения на кругльх столах, организуемьг Комитетом Министров ЕС, Учреждение Европейского Омбудсмана было отчасти обусловлено введением европейского гражданства. Европейский Омбудсман назначается Европарламентом. Ныне функции паневропейского омбудсмана выполняет Джейкомб Содерман.

Европейский Омбудсман - это несудебньй орган, в чью компетенцию входит гарантирование политических, гражданских и социальных прав граждан, которые ушемляются институтами Сообщества.

\section{История создания института Европейского Омбудсмана}

Предложение о введении европейскогс гражданства было официально представлено испанской стороной в 1991 г. в рамках Межправительственной конференции. В соответствии с предложением Испании, принятие каталога специальньх прав для граждан ЕС должно сопровождаться учреждением специальных органов, ответсгвенньх за гарантирование этих прав. Критицизм, направленный на бюрократизацию и отдаленность многих институтов Сообщества, являлся разумным и оправданным. Предложение Испании было в дальнейшем одобрено Данией государством, где омбудсман зарекомендовал себя как высоко-

- Доктор юридических наук, профессор Московской государственной юридической ахадемия. 
эффективный институт. Институт Европейского Омбудсмана был утвержден на политическом уровне Европейским Советом в Риме. Несколькими месяцами позже в феврале 1991 г. испанская делегация представила новое, развернутое предложение, касающееся европейского гражданства. При этом указьвалось на необходимость функционирования в каждом Государстве-Члене Омбудсмана, который помогал бы гражданам Союза в определении их прав в Европейско́м Союзе перед административными властями Союза и их Государств-Членов, а также обращаться за зашитой этих прав в судебные органы по собственному усмотрению или в поддержку заинтересованньх лиц. Он призван также прояснять и дополнять информацию о правах грахдан Союза и средствах их осуществления. В то же время испанская делегация указала, что должны быть рассмотрены две другие возможности: 1. Поручение вышеназванной функции Европейскому Омбудсману как независимому органу Союза или органу, ответственному перед Европейским Парламентом; 2. Повышение эффективности деятельности национальньг Омбудсманов с помошью Омбудсмана, функшионируюшего на наднациональном уровне.

Идея учреждения Европейского Омбудсмана встретила серьезные возражение, прежде всего, со стороны Европейского Парламента. По его мнению, представленному в мае 1991 г., Европейский Омбудсман будет посягать на полномочия Парламента и его Комитетов по осуществлению надзора за Комиссией и ее подразделениями и дублировать деятельность Комитета по петициям. Существующие различия между национальными правовыми системами и правовой системой Сообщества делают невозможным просто и легко "транспортировать" институт Омбудсмана в систему Сообшества. Те же самые оговорки были высказаны национальными Омбудсманами и председателями национальньх парламентских комитетов по петициям на совещании в марте 1991 г., когда Комиссия представила предложения об учреждении Европейского Омбудсмана, как это обсуждалось в рамках Межпарламентской Конференции по политическому союзу.

В проекте Договора о Европейском Союзе право на петиции в Европейский Парламент в некоторой степени ограничивалось оговоркой о том, что петиции в Европейский Парламент будут приемлемы, если они прямо касаются индивида. В то же самое время проект Договора ограничивал юрисдикшию Европейского Омбудсмана только исследованием случаев "плохого управления" в деятельности институтов или органов Сообшества. Проект подчинял Омбудсмана Европейскому Парламенту, предусматри- 
вая, что последний должен избирать Омбудсмана. Этот компромисс удовлетворил Сообщество и Государства-Члены. Тем не менее, ныне некоторые эксперты выражают сомнение относительно того, был ли этот компромисс в интересах грахдан Союза, для которьх и предлагалось, в конечном счете, учредить Омбудсмана ${ }^{1}$.

Ст. 8d Договора о ЕС предусматривает, что каждый гражданин Союза может обратиться в Омбудсману, учрежденному согласно ст. 138е. В соответствии со ст. 138е Договора о ЕС Европейский Омбудсман уполномочен получать жалобы от любого физического или юридического лища, проживающего или имеющего зарегистрированный офис в Государстве-Члене, касаюшиеся случаев "плохого управления" в деятельности институтов или органов Сообщества, за исключением Суда Правосудия и Суда Первой Инстанции, действующих в качестве судебньх органов. Те же самые права предусмотрены ст. 20d договора о сообшестве угля и стали и ст. $107 \mathrm{~d}$ Договора о Евроатоме. Положения о праве на обращение к Европейскому Омбудсману могут быть также обнаружены в Решении Европейского Парламента о положениях и общих условиях, регулирующих выполнение обязанностей Европейского Омбудсмана В соответствии со ст. $138 \mathrm{e}$ Договора o ЕС Европейский Парламент после получения мнения от Комиссии и с одобрения Совета, принявшего решение квалифицированным большинством голосов, может издавать распоряжения и определять общие условия, касающиеся выполнения обязанностей Омбудсмана.

В октябре 1993 г. открылась Межинституциональная Конференция в Люксембурге, которая приняла Межинституционаљьную Декларащию о демократии, транспарентности и субсидиарности. Далее Европейский Парламент, Совет и Комиссия как институты Европейского Союза заключили три отдельньх Межинституциональньх соглашения в рамках Конференции . 1. О процедурах имплементации принципа субсидиарности. 2. О правовьх нормах, регулирующих процедуры в Комитете по примирительным процедурам в соответствии со статъей $189 \mathrm{~b}$ ЕС. 3 . О проекте Решения Европейското Парламента, устанавливаюшего положения и обшие условия, касаюшиеся выполнения обязанностей Омбудсмана. Вслед за этим на пленарном заседания в ноябре 1993 г. Европейский Парламент одобрил Резолюцию о вьшеназванньх Межинституциональньх соглашениях, одобряюшую решение о положениях и обших условиях, регулирующих выполнение обязанностей Омбудсмана, и поручил Председателю Парламента подписать Решение и опубликовать его в Официальном Журнала Европейских Сообществ, как только Совет официально его одобрит. 
В соответствии со ст. 2 вышеназванного Решения Европейского Парламента любой гражданин Союза или любое физическое или юридическое лицо, проживающее или имеющее зарегистрированный офис в Государстве-Члене Союза, может прямо или через члена Европейского Парламента подать жалобу Омбудсману на "плохое управление" в отношении институтов или органов Сообщества, за исключением Суда правосудия и Суда Первой Инстанции, действующих в юридическом качестве. Как только жалоба поступила к Омбудсману, он обязан информировать заинтересованный институт или орган.

\section{Форма и содержание жалобы}

Жалобы могут быть поданы в письменной форме, хотя специальной формы не требуется. По аналогии с петициями жалобы должны быть написаны на одном из официальных языков Сообщества. Они направляются Омбудсману непосредственно или через членов Европейского Парламента. В противоположность петициями жалобы должны быть представлены индивидуально, а не совместно с другими гражданами или лицами. Это означает, что подача групповых жалоб исключается. Жалоба должна быть адресована Европейского Омбудсману или членам Европейского Парламента с просьбой передать ее Европейскому Омбудсману. Эксперты высказывают сомнение в том, что жалоба, поданная политической группе Европейского Парламента, также может быть передана ею Омбудсману. Заявление также должно определять цель жалобы. Лица могут просить о том, чтобы их жалоба оставалась конфиденциальной.

Приемлемость жалоб

Исследование приемлемости жалоб разделено на две стадии. Первая стадия касается формальной приемлемости, а вторая материальной приемлемости. Формальная приемлемость имеет место, если в жалобе имеются следуюшие данные, касаюшиеся заявителя:

имя и фамилия,

грахданство,

постоянный адрес,

его подпись (или подпись адвоката, действующего от имени физического лица, имеющего право на подачу жалобы).

В случае обращения с жалобой юридического лица заявление должно содержать:

титул юридического лица,

название Государства-Члена, в котором зарегистрирован его офис,

адрес офиса,

подпись юридического представителя юридического лица. 
Материальная приемлемость имеет два аспекта: субъект представления жалобы ratione personae и предмет жалобы ratione materiae. Договоры не предусматривают, что жалоба должна прямо касаться заявителя. По мнению некоторых экспертов, позиция Европейского Парламента и Комитета по петициям Европейского Парламента, которые требуют, чтобы жалобы подавались лишь в случае прямой заинтересованности заявителя, не может быть поддержана. Любая попытка установить третий аспект материальной приемлемости приведет к ограничению права на обращение к Омбудсману и будет противоречить Договорам о Европейских Сообществах.

Гражданство ЕС новая политическая и юридическая ка'єеория в праве ЕС. В соответствии со ст. 8 Договора о ЕС каждое лицо, являющееся гражданином Государства-Члена, является гражданином Союза. Проживание - это одновременно юридическая категория и фактическое состояние дел. Если проживание считается юридической категорией, то должна быть воспринята интерпретащия понятия "проживание", даваемая самим Сообшеством. Любая отсылка к национальным положениям, касающимся проживания, будет подрывать единство права на обращение $\mathbf{x}$ Европейскому Омбудсману, что ведет к неравенству. Если проживание считается фактическим положением дел (из договоров непонятно, относятся ли его положения к легальньм или нелегальным эмигрантам), то сомнительно, вправе ли нелегальные эмигранты обращаться к Европейскому Омбудсману. В любом случае их жалобы могут использоватъся Омбудсманом как информации, оправдывающая его действия по собственной инициативе.

Имеются три ключевьх проблемы, касающиеся приемлемости по предмету жалобы:

1. Значение выражения "плохое управление".

2. Определение институтов или органов Сообщества, упомянутых в ст. 138t Договора о ЕС.

3. Могут ли национальные власти, ответственные за имплементацию права Сообщества, находиться в сфере надзора Европейского Омбудсмана?

Случаи "плохого управления" могут охватьвать:

действия администрации Сообщества при отсутствии должньгх полномочий или на несоответствующих основаниях, или согласно ошибочной информации,

административные нарушения нормы,

злоупотребление властью администрацией ЈЈобщества или должностными лищами,

административные действия или практика, основанные на незаконньх процедурах, 
административная практика, которая является дискриминационной или противоречит принципу справедливой и законной администрации,

административные действия, принятые в результате небрежности,

административные упушения,

неправильная работа, некомпетентность, задержка или отказ предоставить ответ администрацией Сообщества в ее отношениях с гражданами Союза, административные действие, которые нарушают понятие равенства.

За пределами понятия "плохое управление" находятся:

политические решения, принятые институтами Сообшества,

законодательные акты, принятые в рамках ст. ст. 189a, 189b, 189c Договора о ЕС,

петиции (в этих случаях Омбудсман может посоветовать гражданину обратиться в Комитет по петициям Европейского Парламента).

Комитет по петициям Европейского парламента является главным образом политическим органом. Но выполняет квазисудебную функщию, рассматривая петиции европейских граждан по любому вопросу, за исключением чистьх случаев "плохого управления".

Европейский Омбудсман должен воздерживаться от рассмотрения жалоб, которые касаются широких политических вопросов или подразумевают осуществление политического контроля за функционированием институтов Сообщества.

В сфере компетенции Европейского Омбудсана находятся институты, предусмотренные ст. 4 Договора о ЕС: Совет, Комиссия, Европейский Парламент, Суд Аудиторов, а также Суд правосудия и Суд Первой Инстанции, когда они не действуют в судебном качестве, Экономический и Социальный Совет, Комитет по делам регионов, Европейский Инвестиционный Банк, Европейский валютный Фонд, Общий центр исследований и все иные органы Сообщества.

Вопрос о том, подконтрольны ли Омбудсману национальные власти, имплементирующие право Собщества, является очень важньм. Комитет по петициям Европейского Парламента считает, что Омбудсман не может исследовать жалобы на соответствующие органы. Более того, в соответствии с пар. 1 ст. 2 Решения Европейского Парламента об обязанностях Омбудсмана, действия властей или лиц, не указанные в ст. 138е Договора о ЕС, не могут быть обжалованы Омбудсману.

Временные предељы

В соответствии со ст. 2 Решения Европейского Парламента 
об обязанностях Омбудсмана жалоба должна быть подана в течение 2 лет со дня, когда факты, на которьх основана жалоба, стали известны заявителю.

Исчерпавие соответствуюших административньх процедур

В соответствии со ст. 1 параграфа 4 вышеназванного Решения Европейского Парламента, жалобе должны быть предпосланы соответствующие административные попытки (подходы) заинтересованньх органов и институтов. Европейский Омбудсман не вправе рассматривать жалобы, связанные с трудовыми отношениями между Сообшеством и его должностными лицами, если процедуры, относящиеся к ст. 90(1) и (2) Правил о персонале, не были исчерпаны заинтересованньми лицами и не истекли сроки для ответа соответствующих властей.

Факторы, ограничивающие действия Европейското Омбудсмана

Европейский Омбудсман не может оспаривать обоснованность решений Суда соответствии с параграфом 3 ст. 1 Решения Европейского Парламента.

В соответствии с параграфом 7 ст. 2 Решения Европейского Парламента Омбудсман обязан признать жалобу неприемлемой или приостановить ее рассмотрение, если он знает, что изложенные в ней факты стали предметом судебного разбирательства, которое все еще продолжается или завершено рассмотрение вопросов по существу. Если жалоба была признана обоснованной, Европейский омбудсман безотлагательно и в письменной форме информирует лищо, подавшее халобу, о предпринятьх действиях. Далее, в соответствии со ст. 2 Решения Европейского Парламента, упомянутого вьпе, Омбудсман должен:

содействовать обнаружению случаев "плохого управления" в деятельности институтов или органов Сообщества;

дать рекомендации о том, каким образом прекратить плохое управление".

При расследовании Омбудсмана институты и органы могут представить любые полезные комментарии.

Омбудсман вправе провести расследование по собственной инициативе. Инициативные действия Омбудсмана опражданы, если он получил подтверждение случаев плохого управления от прессы, телевидения либо из Резолюции Европейского Парламента.

Полномочия Омбудсмана по получению информации стали вопросом разногласий мехду Европейским Парламентом и Советом. Европейский Парламент занял благоприятную для Омбудсмана позицию. В Проекте вышеупомянутого Решения он предусмотрел, что даже секретность информации (все документы и записки Комиссии) не является препятствием для ее получения 
Омбудсманом, если информация прямо или косвенно касается вопросов, являющихся предметом жалобы. Точка зрения Совета была более жесткой. Препятствием для предоставления информации Совет счел ее конфиденциальность и профессиональную секретность.

После интенсивных консультаций Европейский Парламент и Совет согласились на компромисс. В Проекте Решения было предусмотрено, что основанием отказа институтов Сообщества в информации является ее долхным образом оправданная секретность. Проект предусматривал, что все соответствии с предварительным соглашением с заинтересованным ГосударствомЧленом органы Сопбшества будут также передавать документы, исходяцие от Государства-Члена, которые предусмотрены законами или постановлениями о секретности или любьми друтими нормами, предотвращающими их публичную огласку. При согласии заинтересованного государства Омбудсман может знакомиться с содержанием документов, но не разглашать их. Должностные лица и другие служашие институтов и органов Сообщества были обязаны давать показания (свидетельствовать) по запросу Омбудсмана и от имени или по указанию их администрации. Они остаются связанными обязательствами секретности. Проблема была окончательно решена после подписания Межправительственного соглашения об обязанностях Омбудсмана.

В соответствии с параграфом 3 Решения Европейского Парламента об обязанностях Омбудсмана заинтересованные институты и органы Сообщества обязаны представлять Европейскому Омбудсману запрашиваемую информацию и доступ к документации.

В этом случае институты и органы Сообщества могут отказаться давать информацию только по наллежашим образом обоснованным соображениям секретности. Более того, они обязаны предоставить документы, исходящие от Государства-Члена и .являющиеся секретными в соответствии с законом или постановлениями, только в случаях, когда Государство-Член даст на это предварительное разрешение. В этом положении в полной мере проявился принцип субсидиарности, заложенный в природе ЕС. Что касается других документов, имеюших происхождение в Гоударстве-Члене, то органы или институты Сообщества открывают к ним доступ после того, как соответствующее Государство-Член будет об этом проинформировано.

По вопросу об обязанностях Государств-Членов между Европейским Парламентом и Советом также возникли разногласия. Европейский Парламент первоначально полагал, что власти Государства-Члена обязаны по запросу Омбудсмана обеспечивать 
его любой информаџией, которая может прояснить случаи "плохого управления" со стороны институтов и органов Сообщества. Совет выступал против непосредственньх контактов Европейского омбудсмана с национальными властями и предложил, чтобы кахдое обращение от имени Европейского Омбудсмана адресовывалось Постоянным Представителем Государства-Члена Европейских Сообществ. По мнению Совета, национальные власти были обязаны обеспечивать Омбудсмана информащией, которая могла помочь выявить "плохое управление", за исключением случаев профессиональной секретности или хонфиденциальности, определяемьх законодательством Государства-Члена.

В компромиссном тексте, одобренном генеральным секретарями Европейского Парламента и Советом, предусматривалось, что национальные власти могли отказаться предоставить информацию Омбудсману только на основании секретности, определяемой законодательством Государства-Члена. В соответствии со ст. 3 Решения Европейского парламента об обязанностях Омбудсмана, Омбудсман может запросить через Постоянного Представителя Государства-Члена ЕС, у органа Государства-Члена любую информацию, которая мохет прояснить случаи "плохого управления" институтами или органами Сообщества. Государства-Члены могут отказаться предоставить запрашиваемую информацию, только если информация охватывается законами или распоряжениями о секретности или положениями, предотвращающими ее разглашение.

В случае обнаружения "плохого управления" Омбудсман информирует об этом заинтересованные институты и органы Сообществ, предлагает свои рекомендации по их устранению. Институты и органы обязаны направить Омбудсману обоснованное изложение своей позиции по делу в течение 3 месяцев.

При об̆наружении кахдого случая "плохого управления" Омбудсман представляет Европейскому Парламенту доклад о результатах расследования. В конце кахдой ежегодной сессии Омбудсман должен направить Европейскому Парламенту доклад о результатах своих расследований.

Омбудсман и его персонал обязаны не разглашать информацию или документы, которые они могут получить в результате своих расследований. Они также должны сохранять конфиденциальность любой информации, которая мохет причинить вред заявителю или любому вовлеченному в расследование пицу. Если Омбудсман в процессе расследования на основании выявленных фактов полагает, что вопрос имеет отношение к уголовному праву, он должен немедленно известить компетентные национальные власти через Постоянното Представителя Государства-Члена в 
Сообществах и, если это требуется, институт Сообщества, имеющий властные полномочия в отношении должностного лица или служащего, которьй может применить пар. 2 ст. 18 Протокола о привилегиях и иммунитетах Европейских Сообществ. Омбудсман может также информировать институты или органы Сообщества о фактах, которые ставят под вопрос поведение членов их персонала с дисциплинарной точки зрения.

Роль Европейского Суда Правосудия.

Действия, предпринимаемые Европейским Парламентом

В соответствии с параграфом 4 ст. 3 вьпшеназванного Решения Европейското Парламента, если не ожидается помощи в ответ на запрос Омбудсмана, последний может информировать Европейский Парламент, которьй делает соответствуюшие представления. Решение Европейского Парламента не определяет значения термина "представление". Эксперты полагают, что Европейский Парламент, помимо официального представления в отношении не выполняющего свои обязательства института Сообщества, может принять резолюцию как финальное действие на политическом уровне для того, чтобы побудить Государство-Член или институт Сообщества выполнять свои обязательства и сотрудничать с Европейским Омбудсманом.

Кроме того, соответствующие действия судебньх органов также не могут быть исключены. Они могут принять форму официального требования Европейского Парламента к Комиссии в соответствии со ст. 175 Договора о ЕС начать производство на основании ст. 169 Договора о ЕС против Государства-Члена. В этих случаях если Комиссия отказывается действовать, Европейский Парламент может обратиться в Суд правосудия за получением решения о ее неспособности действовать. Этот подход принимается не без возражения со стороны специалистов в сфере права ЕС, так как в терминах ст. 169 Комиссия не может преследоватъся в судебном порядке.

Тем не менее, в свете казусного права Суда, касаюшегося исков “непривилегированных заявителей", можно предположить, что в будушем нельзя исключить возможность вынесения решения Суда, которое ограничивает в определенных случаях и при определенньх обстоятельствах широкое усмотрение Комиссии в вопросе о возбуждении производства против ГосударстваЧлена в соответствии со ст. 169 Договора о ЕС.

Возможен также иск против Комиссии и Совета. В соответствии со ст. 173 Договора о ЕС, Европейский Парламент может доказать, что нарушение прерогатив Европейского Омбудсмана считается нарушением прерогатив Еврейского Парламента.

Кроме того, Европейский Парламент может использовать ст. 
175 Договора о ЕС и подать иск против Комиссии или Совета о неспособности сотрудничать с Европейским Омбудсманом.

\section{Иски Европейского Омбудсмана}

Способен ли Европейский Парламент защитить прерогативы Европейского Омбудсмана? Может ли Европейский Омбудсман представить перед Европейским судом правосудия иск в соответствии со ст. 173 Договора о ЕС, чтобы зашитить свои прерогативы против действий институтов Сообщества, включая Европейский Парламент? По мнению экспертов, такая эволюция не исключена и соответствует казусному праву Европейского Суда Правосудия в сфере защиты прерогатив Европейского Парламента.

Далее, может ли Европейский Омбудсман использовать ст. 175 Договора о ЕС против Европейского Парламента. Совета или Комиссии, если эти институты отказываются с ним сотрудничать? Согласно букве Договора о ЕС, такое право не предоставлено Омбудсману, так как им располагают лишь институты, перечисленные в ст. 4(1) Договора о ЕС, Скорее всего, такой иск Омбудсмана будет отвергнут судом как неприемлемый. В этом случае может ли иск Омбудсмана квалифицироваться в соответствии с параграфом 3 ст. 175 Договора о ЕС. Основываясь на казусном праве Суда, можно предположить, что реализация данного права может бьть потенщиальньм способом действий Омбудсмана на юридическом уровне. С другой стороны, сомнительно, допустимо ли это с политической точки зрения, либо может расцениватъся как умаление статуса Омбудсмана до простого юридического лица, тогда как он является институтом Сообщества.

\section{Европейский Омбудсман как ответчик}

Положение Омбудсмана как ответчика может быть выведено из ст. 178 Договора о ЕС в соответствии со ст. 4 Решения Европейского Парламента об обязанностях Омбудсмана. Омбудсман и его персонал связаны ст. 14 Договора о ЕС, ст. 47(2) Договора о Европейском сообществе угля и стали и ст. 194 Договора в Евратоме. В особенности они обязаны не раскрывать информацию или документы, которые они получили в процессе своих расследований. Далее, они обязаны сохранять конфиденциальность любой информации, от которой могут пострадать лица, подавшие жалобу, или любые вовлеченные в расследование лица, без ущерба для параграфа 2 ст. 4 вышеупомянутого Решения Европейского парламенга. Это особенно важно в случаях, когда заявитель в своей жалобе просит, чтобы она оставалась конфиденциальной. Может ли лищо, пострадавшее в результате нарушения Омбудсманом этих обязанностей, преследовать Сообщество за ущерб в соответствии со ст. 178 и ст. 215 Договора о ЕС?

Существует точка зрения, что это невозможно, поскольку 
Омбудсман не упомянут среди институтов Сообщества, перечисленньх в соответствующей статье. Однако этот аргумент не может бьть принят, поскольку он противоречит намерениями основателей Сообщества. Омбудсман - это орган Сообщества и уполномочен действовать от его имени. Неконтактная ответственность Омбудсмана вполне допустима. В любом случае Европейский суд правосудия будет окончательным арбитром в этом вопросе и заполнит, как обычно, вакуум в праве Сообщества.

Европейский Омбудсман - это институт, который, в случае правильного использования, может гарантировать гражданам Сообщества важное и бесплатное средство защиты против европейской бюрократии. Это очень важно для консолидации транспарентности (прозрачности), которая является существенным элементом развития взаимного доверия мехду Союзом и его грахданами.

1 Epaminondas A. Maris. The European Ombudsman: Competencies and Relations with Other Community and Bodies. - The Modem Law Review. Vol. 58. № 2. March 1995. P. 71-91.

\title{
СОЦИАЛЬНОЕ-ЭКОНОМИЧЕСКИЕ ПРАВА И СВОБОДЫ В ГОСУДАРСТВЕ ПЕРЕХОДНОГО ПЕРИОДА
}

\author{
Г.A. $\mathrm{K}$ о p о 6 о $\mathrm{B}^{*}$
}

Стало расхохим мнением, что признание Российского государства правовым на сегодняшний день нельзя рассматривать как реальность, а всего лишь как одну из задач будущего (и весьма неблизкого к сожалению). В частности, профессор В.С. Афанасьев выразил эту точку зрения следуюшим образом: “... формирование правового государства в современных условиях не более реально, чем построение развитого социализма или общенародного государства"'. Можно согласиться и с Л.Б. Тиуновой, выделяющей в дополнение к общеизвестным признакам правового государства "относительно высокий уровень матери-

* Доцент кафедры Государственного и административного права Воронежской высшей школы МВД РФ, кандидат юридических наук. 